\title{
Yeni Toplumsal Hareketler ve "Bir Araya Gelmenin Koreografisi” Bağlamında Video Aktivizm
}

\author{
New Social Movements and Video Activism in the Context of "Choreography of \\ Assembly"
}

\section{Erdem YEDEKC $\dot{I}^{*}$}

\section{Öz}

Kapitalist sistemde ortaya çıkan materyalist değerlerden post-materyalist değerlere doğru yöneliş, toplumsal hareketlerin amaç ve örgütlenme biçimlerinde de bir takım değişimler meydana getirmiştir. Bununla birlikte, tarihin hangi döneminde ortaya çıkmış olursa olsun, tüm toplumsal hareketler için olmazsa olmaz tek şey, medya araçlarının etkin kullanımıdır. Toplumsal hareket aktörlerinin bir araya gelmesinde kilit bir noktada bulunan medya araçları, kendi içlerindeki farklılaşmaya bağlı olarak, toplumsal hareketlerin örgütlenme biçimlerinde de bir takım dönüşümlere yol açmaktadır. Bugün dönemin koşullarına en uygun medya aracı olarak yeni medya, kendi çok katmanlı yapısına koşut biçimde farklı toplumsal arka plana ve beklentilere sahip bireylerin, toplumsal problemler karşısında birlikte hareket etmelerini mümkün kılmıştır. Bu çalışmada, videonun toplumsal hareketlerin sosyal medyada örgütlenme sürecindeki rolünün ortaya konması amaçlanmaktadır. Bu doğrultuda, söz konusu süreci "bir araya gelmenin koreografisi" biçiminde kavramsallaştıran Paolo Gerbaudo'nun kuramı üzerinden video aktivizm kavramı açıklanarak videonun insanları ortak problemler karşısında birlikte hareket etmeye motive edici potansiyeli Gezi Parkı eylemleri üzerinden vurgulanacaktır.

Anahtar Kelimeler: Medya, Toplumsal Hareketler, Video Aktivizm, Dijital Aktivizm, Bir Araya Gelmenin Koreografisi, Gezi Parkı Eylemleri

\section{Abstract}

The shift from materialist values to post-materialist values in the capitalist system has brought a number of changes on the purpose and structure of social movements. However, in every period of history, the only essential thing for all social movements is the effective use of media tools. Depending on their differentiation, media tools, which are at a key point for gathering of social movement actors, lead to a number of transformations in the way social movements organize. Today, new media as the

Arş. Gör., Marmara Üniversitesi, İletişim Fakültesi, İstanbul, Türkiye, erdem.yedekci@marmara.edu.tr. 
most suitable medium in the conditions of the period; parallel to their multi-tiered structure, has made it possible for individuals with different social backgrounds and expectations to act together against social problems. In this study; it is aimed to reveal the role of video in the process of organizing social movements via social media. In this sense, explaining the concept of video activism through the theory of Paolo Gerbaudo, who conceptualizes the process as "choreography of assembly", the motivational potential of video to move people together against common problems will be emphasized through the Gezi Park protests.

Keywords: Media, Social Movements, Video Activism, Digital Activism, Choreography of Assembly, The Gezi Park Protests.

\section{GiRiş}

Tarihte toplumsal hareketlerin ilk örnekleri, burjuvazi ile proletarya arasındaki mücadelenin somut bir zemine taşındığı 19. yüzyıldaki işçi hareketleriyle görülmeye başlar. Bu dönemdeki toplumsal hareketlerle amaçlanan, siyasi iktidarı ele geçirme yoluyla, toplumdaki sosyo-ekonomik eşitsizlikleri ortadan kaldırmaktır. İkinci Dünya Savaşı̉ıın ardından iktidara gelen sosyalist hareketlerin, muhalif kesimlerde yarattığ düş kırıklığı da, tarihte yeni bir toplumsal direniş tarzının ortaya çıkmasına neden olmuştur. Bu yeni direniş biçiminin miladı ise Mayıs 1968'de Fransa'daki öğrenci hareketleridir. Bu hareketler, sistemin verili değerlerine yönelik bir başkaldırı olmasının yanında, toplumsal hareketlerden geçmişte edinilmiş deneyime karşı ortaya çıkan bir reflekstir de aynı zamanda. Yeni toplumsal hareketler olarak adlandırılan bu hareketlerle amaçlanan, toplumun aksayan yönlerinin onarılmasıdır. Bu bağlamda, sorumluların harekete geçirilebilmesi maksadıyla, kamuoyunun ve medya kuruluşlarının dikkatinin çekilebilmesi önemlidir.

Toplumsal hareketlerin ortaya çıkmasında medya önemli bir rol üstlenmiştir. Çünkü ister muhalif ideolojinin yeniden-üretimi, isterse haberleşme ve koordinasyon amacıyla olsun her türlü bilginin kitlelere aktarımı dönemin şartlarına uygun medya araçlarıyla mümkün olabilmektedir. Bugün, çağın ruhunu en iyi yakalayan yeni medyanın sunduğu imkanlar ise toplumsal hareketlerde medya araçlarının etkin kullanımını daha ileri bir noktaya taşımıştır. Bu çalışma, Paolo Gerbaudo’nun "bir araya gelmenin koreografisi” olarak kavramsallaştırdığı toplumsal hareketlerin sosyal medyada örgütlenmesi sorunsalını video aktivizm kavramı bağlamında ele almaktadır. Bu nedenle öncelikle, toplumsal hareketlerin örgütlenmesinde videonun rolünün daha net bir şekilde anlaşılabilmesi için toplumsal hareketlerin gelişimi tarihsel olarak betimlenecektir. Daha sonra, yeni iletişim teknolojilerinin toplumsal örgütlenmelerde neden ve nasıl kullanıldıkları izah edilerek konu, video aktivizm ve toplumsal hareketler bağlamında açıklanacaktır. Son olarak, çalışmayı somut temellere oturtabilmek adına Gezi Parkı eylemleri bu bağlamda analiz edilmeye çalışılacaktır. 


\section{“Eski"sinden “Yeni"sine Toplumsal Hareketler}

Toplumsal hareketler ilk olarak, 19. yüzyılın sonlarında ortaya çıkan işçi hareketleri ile başlamıştır. 68 Hareketi’ne kadar görülen tüm toplumsal hareketler, iş̧̧i hareketlerinde olduğu gibi siyasi iktidarı hedefleyen, ekonomik çıkar ekseninde sınıf temelli hareketlerdir. Bu tür hareketler, eskide kalan endüstri toplumuna ait oldukları manasında, "eski toplumsal hareketler" olarak tanımlanmaktadırlar (Önder, 2003, s. 34-35; Çayır, 1999, s. 16). Eski toplumsal hareketlerde, sorunlar karşısında ortaya atılan çözüm önerilerinde, harekete katılanların savunduğu ideolojiler büyük önem arz etmektedir (Hank, Larana ve Gusfrield, 1999, s. 151). Vehbi Bayhan’ın (2014) da belirttiği gibi, "devrim fikriyle özdeşleşmiş ve neredeyse bir siyasal partinin ya da siyasal hareketin gölgesinde şekillenen iş̧̧ hareketi bu tip hareketlerin en iyi örneklerinden biridir. Bu hareketin içindeki işçiler, birer aktörden ziyade tarihsel bir zorunluluğu yerine getirmek için mücadele eden figürlerdir" (s. 26). "Yeni toplumsal hareketler" kavramılla anlatılmak istenen ise, 68 Hareketi'nin ardından, özellikle 1970’li yılların başında görülmeye başlanan çevreci hareketleri, feminist hareketleri, savaş ve nükleer karşıtı hareketleri, azınlık ve yerel özerklik hareketlerini kapsayan ve toplum içindeki farklı talepleri dile getiren hareketlerin tümüdür (Önder, 2003, s. 34-35). Bu tip hareketlerle toplumsal dönüşümden çok, rahatsız olunan bir konuya, kamuoyunun ve medya kuruluşlarının dikkatinin çekilerek sorumlular tarafından çözüm sağlanması amaçlanmaktadır (Şentürk, 2006, s. 31).

Yeni toplumsal hareketlerin adem-i merkeziyetçi, anti-otoriter ve esnek bir yapıya sahip olmasının temelinde, bu hareketlerin toplumun metalaşmasına, bürokratikleşmesine ve homojenleşmesine karşı bir tavırla ortaya çıkmış olmalarının yanında, sosyal kurumları özgürlükçü bir tarzda dönüştürme çabaları da yer almaktadır (Offe, 1999, s. 69). Eski toplumsal hareketler, gelir dağılımındaki eşitsizliğin ortadan kaldırılması gibi maddi amaçlar doğrultusunda mücadele eden sosyo-ekonomik gruplardan oluşurken, yeni toplumsal hareketler toplumun farklı ilgi ve beklentilere sahip kesimlerinden insanların, farklı toplumsal ve siyasal problemler etrafında bir araya gelerek oluşturdukları değişik gruplardan meydana gelmektedir (Offe, 1999, s. 53-66). Dolayısıyla, yeni ile eski toplumsal hareketlerin toplumsal tabanlarını oluşturan aktörlerin sınıfsal aidiyetleri de değişiklik göstermektedir. Eski tip hareketlerde, ekonomik bir temelde tanımlanan sınıfsal ayrım ön plana çıkarken, yeni toplumsal hareketlerde değişik sosyal sinıflardan insanların bir aradalığı görünür olmaktadır.

Eski toplumsal hareketlerden, yeni toplumsal hareketlere doğru olan bu dönüşümün temelinde kapitalist sistem içinde ortaya çıkan yeni ücretlilik sistemleri ve teknolojik ilerlemelere bağlı olarak işçi sınıfının dışında, farklı bir ücretli çalışanlar sınıfının ortaya çıkması durumu yer almaktadır. Ortaya atılan "yeni sınıf" teorilerine göre Marx, burjuva ile emekçi sınıf arasında ortaya çıkan "yeni orta sınıfı" bütünüyle görmezden gelmiştir. Buna paralel olarak, sosyalizmle birlikte sınıfsız bir topluma geçileceğine dair umutlar da son bulmuştur. İleri kapitalist toplumda ortaya çıkan bu yeni orta sınıfla birlikte, yalnızca alınan ücretler ve yapılan iş açısından ayrımlar ortaya çıkmamış, aynı zamanda materyalist değerlerden post-materyalist değerlere, sınıf temelli siyasi mücadelelerden değer temelli siyasi mücadelelere doğru kaymalar da meydana gelmiștir. Böylelikle, yeni orta sınıfa mensup kişilerce benimsenen değerler ekonomik çıkar temelli eski tip 
sınıfsal hareketlerde değil, yeni toplumsal hareketler ya da "kimlik yönelimli hareketler" olarak adlandırılan hareketlerde karşılığını bulmuştur. Bunun sebebi, artık endüstri toplumuna ait araçsal sorunların geride bırakılmış ve içinde yaşadığımız endüstri sonrası topluma dair yaşamsal problemlerin toplumsal hareketlerin ana odağı haline gelmiş olmasıdır. Yeni toplumsal hareketler tam da bu noktada, eski toplumsal hareketlerden niteliksel anlamda farklılık göstermektedir: Yeni toplumsal hareketlerin "aktörlerinin çıkarları, sınıfsal konumlarından değil, çıarlarını kendilerinin belirledikleri, siyasal konumlarından gelmektedir” (Coşkun, 2006, s. 68-69).

$\mathrm{Bu}$ durumu daha iyi kavrayabilmek için, Alain Touraine'in "programlanmış toplum" kavramsallaştırmasına başvurmak yerinde olacaktır çünkü, eski toplumsal hareketler gibi yeni toplumsal hareketler de ortaya çıktıkları toplumun koşullarından bağımsız olarak düşünülemez (Çayır, 1999, s. 16). Touraine (1995), "programlanmış toplum” kavramını post-endüstriyel toplum mefhumunu ifade etmek amacıyla kullanmaktadır. Ona göre, programlanmıs toplum, tarihte yeni bir aşama olarak karşımıza çıkmaktadır. Maddi tüketim mallarının merkezi bir konumda yer aldığı endüstri toplumundan farklı olarak bu toplum tipinde, kültürel malların kitlesel olarak üretim ve tüketimi merkezi bir konumda bulunmaktadır. Endüstri toplumunda demir-çelik, tekstil gibi işkolları ne ifade ediyorsa, programlanmış toplumda da eğitim, sağlık ve kitle iletişimin üretimi ve yeniden-üretimi aynı şeyi ifade etmektedir (s. 272). Programlanmış toplumda bireylerin, malların ve fikirlerin daha önce hiçbir toplumda görülmemiş oranlarda dolaşıma sokulması olgusu bu tür toplumlarda yöneten ile yönetilen arasındaki mesafeyi giderek büyütmektedir. Bu durumun bir uzantısı olarak, özel hayat ve kültürel alan, siyaset alanının sınırları içine girerken, bireysel yaşam daha önce hiç olmadığı kadar kamusal bir şey haline gelmektedir. Böylelikle, meydana gelen toplumsal çatışmalarda merkezi bir konum edinen özel yaşam nosyonu, yeni toplumsal hareketlerin de ana odağını oluşturmaktadır (aktaran Coşkun, 2006, s. 70-71). Coşkun'un (2006) ifadesiyle "toplumsal aktörler artık tarih adına değil, kendi adlarına konuşmakta ve şeylerin gidişatını yönetmeyi istemekten çok kendi özgürlüklerini; iktidar, şiddet ve propaganda araçları tarafından ezilmeden kendileri olabilme hakkını istemektedirler" (s. 71). Sınıf eksenli mücadele ve devrimci örgütlenmenin bazı biçimlerinin zamanının çoktan geçtiğini ve bunların işe yaramaz hale geldiğini vurgulayan Michael Hardt ve Antonio Negri’nin (2004) de ifade ettikleri gibi:

$\mathrm{Bu}$ biçimlerin kimisi taktik ve stratejik hatalar nedeniyle geçersiz kalırken kimisi de isyan bastırma hamleleri sonucunda etkisiz hale geldi; ama bunların ölümünün daha önemli bir nedeni bizzat çokluğun geçirdiği dönüşümdür. Günümüzde toplumsal sınıfların küresel bileşiminin dönüşümü, maddi olmayan emeğin hegemonyası ve ağ yapılarından kaynaklanan yeni karar alma biçimleri, bütün devrimci süreçlerin koşullarını köklü bir biçimde değiştiriyor. (s. 86)

Ernesto Laclau ve Chantal Mouffe (1992) ise Touraine’in yaklaşımına paralel biçimde, yeni toplumsal hareketlerin İkinci Dünya Savaşı̉nın ardından ortaya çıkan yeni hegemonik formasyona koşut olarak geliştiğini belirtmektedirler. İkilinin işaret ettiği süreç, üç aşamada incelenebilir: İlk aşama, ekonomik düzlemde meydana gelmektedir. "Yaygın birikim rejiminden yoğun birikim rejimine" geçilmesiyle, sosyal ilişkilerde yoğun bir metalaşma eğilimi görülmektedir. Bu dönüşüm sonunda, kapitalist üretim ilişkilerinde egemen olan mantık, 
toplumun tüm kesimlerine ve tüm ilişkilerine sızmıştır. İkinci aşama, doğrudan refah devletinin kendi müdahaleci karakterinden kaynaklanmaktadır. Tüm toplumsal ilişkilerin metalaşması sonucunda devlet de, alabildiğine genişlemiş ve çok daha fazla alana müdahalede bulunmaya başlamıştır. Devletin müdahale alanının genişlemesi bürokratikleşmenin de hızını arttırmış ve bu duruma karşı yeni çatışma biçimleri ortaya çıkmıştır. Üçüncü ve son aşama ise, kitle iletişim alanında ortaya çıkan teknolojik gelişmelerdir. Kitle iletişim teknolojilerinin gelişimine paralel olarak, toplumların homojenleştirilmesinde egemenlerce etkili bir silah olarak kullanılan kitle kültürü de büyük bir hızla toplumun tüm kesimlerine yayılmıs ve bunun sonucunda yeni bağımlılık biçimleri ortaya çıkmıştır. Bu noktada, yeni toplumsal hareketlerin, sosyal yaşamın metalaşmasına, bürokratikleşmesine ve tek tipleştirilmesine karşı yeni bir direniş biçimi olarak ortaya çıktığını söylemek mümkündür. İşte tam da bu nedenle yeni toplumsal hareketlerle amaçlanan, eski toplumsal hareketlerde olduğu gibi iktidarı ele geçirmek tarzında bir takım siyasal hedeflere ulaşmaktan çok sivil toplumda özerkliğin sağlanması ve eşitsizliklerin ortadan kaldırılması yönünde kültürel bir takım talepleri dile getirmektir. Bu anlamda, yeni toplumsal hareketler kavramının başına "yeni" sıfatının getirilmesinin en temel nedeni, Laclau ve Mouffe'un bahsettikleri yeni bağımlılık biçimlerine karşı alınan tavırdır (s. 196-201).

\section{Yeni Toplumsal Hareketlerde Yeni İletişim Teknolojilerinin Kullanımı}

Toplumsal hareketlerin başarısında belirleyici olan, eylemin anlık sonucu değil harekete müdahil olan kesimler arasındaki birlikteliğin artarak devam ettirilebilmesidir. Bu noktada Marx ve Engels (2015), modern sanayi tarafından yaratılan ulaşım araçlarına büyük önem atfederler, çünkü muhalif kesimlerin birbirleriyle koordinasyon halinde hareket etmeleri, bu araçlar sayesinde mümkün olabilmektedir (s. 60). Bugün, dünyanın farklı bölgelerindeki pek çok insan modern kapitalist sistemin sunduğu iletişim ve ulaşım imkanlarıyla bağlantıya geçebilmektedir.

$\mathrm{Bu}$ bağlamda, yeni iletişim ve enformasyon teknolojilerindeki gelişmelerle birlikte kitlelerin kullanımına sunulan yeni medya önemli bir yerde konumlanmaktadır. Bunun sebebi, sahipliği yüksek maliyet gerektiren kitle iletişim araçlarının kullanım haklarının eskiden olduğu gibi bugün de sıradan insana kapalı olmasıdır. Bu açıdan, muhalifler tarafından bir kitle iletişim medyasının yaratılması ve varlığının devamlı kılınması oldukça zordur. Gazete, dergi, radyo ve televizyon gibi geleneksel medya araçlarının sahipliğinin, sistemin devam ettirilmesinde çıkarı olan kurum ve kuruluşların hegemonyası altında bulunması, ayrıca bu araçlar üzerindeki devlet hakimiyeti, toplumsal hareket aktörlerini yeni medya teknolojilerine ve özellikle sosyal ağlara yönlendirmektedir. Zira internet, "maliyet anlamında iktidara olduğu kadar muhaliflere de ideolojilerini yeniden-üretme olanağı sağlamaktadır” (Çoban, 2009, s. 57-58). Böylece, geleneksel medyada üretilen, homojenleştirici ve ideolojik içeriğe mahkum olmak zorunda kalmayan bireyler, her türlü formattaki (ses, yazı, video) enformasyona sosyal ağlar aracıllğıyla kolayca ulaşabilmekte, yine bu ağlar aracilığıyla ellerinde bulunan enformasyonu başka kişilerle paylaşabilmektedirler. Bu şekilde, yeni medya teknolojilerinin sunduğu imkanlar sayesinde dünyanın pek çok bölgesinden benzer düşüncelere sahip insanlar, sanal ortamlarda bir araya gelebilmektedirler. 
Manuel Castells (2008), yeni iletişim ve enformasyon teknolojilerinin içinde, toplumda birtakım dönüşümlere yol açabilecek potansiyeli barındırdığını belirtmektedir (s. 623). İnsanlar bu teknolojiler sayesinde eskisinden çok daha kolay ve hızlı bir şekilde birbirleriyle iletişim kurabilmekte ve bir araya gelebilmektedirler. Bu durum, insanların hem gerçek hem de sanal ortamlarda bir araya gelerek rahatsızlık duydukları ortak bir problem karşısında kolektif hareket edebilmelerini ve seslerini çıkarabilmelerini sağlamaktadır. Sosyal ağlarda gerçekleştirilen iletişim, kitlesel bir özellik taşımaktadır. İşte bu gerçeğe vurgu yapan Castells (2013), sosyal ağları dünyanın farklı yerlerinden çok sayıda insan tarafından üretilmiş olan dijital haldeki enformasyonu, dünyanın pek çok yerindeki sayısız insana ulaştıran bir iletişim aracı olarak tanımlamaktadır (s. 21). Sosyal ağlarda içerik üretim ve paylaşım pratiklerinin tümünde kullanıcı kendisi karar vermektedir. Aynı zamanda, kullanıcı/içerik üreticisi, ürettiği içeriğin iletileceği alıcıyı da bir noktaya kadar kendisi belirleyebilmektedir. Diğer taraftan, sosyal ağlarda paylaşılan içeriğin tüketimi de doğrudan internet kullanıcısının kendi inisiyatifindedir. Sosyal ağların tüm bu olumlu özelliklerinin yanında, oluşturulan içeriğin hükümetler ve şirketler tarafından kolayca kontrol altına alınamıyor olması da, sanal ortamların bir diğer önemli artısıdır. Bu sayede, sosyal ağlar aracılığıyla toplumsal hareketler çok daha hızlı bir şekilde planlanabilmekte ve dünyanın farklı bölgelerinden çok sayıda insan eşzamanlı olarak meydanlara inebilmektedir.

\section{Sosyal Ağlarda Bir Araya Gelmenin Koreografisi}

Günümüzde, özellikle 2011 yllından sonra ortaya çıkan toplumsal hareketlerde sosyal ağların rolü pek çok mecrada tartışılmaya devam edilmektedir. Siber-ütopyacılara göre son dönemde yaşanan toplumsal değişimlerin en önemli kaynağı, Facebook ve Twitter gibi sosyal medya platformlarının varlığı iken, siber-gerçekçilere göre bu görüş, gerçek dünya aktivizmini tamamen göz ardı etmektedir. Buna göre, birer dijital araç olan Facebook ve Twitter gibi sosyal ağlar adı üstünde - basit birer araçtan fazlası değildir. Toplumsal değişim, ancak politik kurumlar ve direniş hareketleri ile birlikte sürdürülen uzun süreli uğraşlar ve zahmetler sonucunda mümkün olabilmektedir. Bununla birlikte sosyal ağların, daha genel anlamıyla internetin, toplumsal hareketlerdeki rolünü yok saymak da doğru bir yaklaşım olmayacaktır. Gladwell'in de belirttiği gibi internet, atomize haldeki bireyler yerine, daha iyi organize olmuş halk örgütlenmeleri tarafından kullanıldığında etkili bir siyasi değişim aracı haline gelebilmektedir (aktaran Morozov, 2017, s. 23-24).

Sosyal ağların, toplumsal değişimlerde oynadığı rolü saptamaya çalışırken dikkat edilmesi gereken en önemli husus, araca yüklenen anlamı çok yönlü bir bakışla belirlemeye çalışmaktır. Zira bugün, "Online’ım, öyleyse varım!" (Sabancı, 2017) çağında, gerçek hayattaki varoluşumuzu görünür kılabilmemiz neredeyse tamamen sanal alanda kendimize ait bir alan oluşturmamız ön koşuluna bağlı hale gelmiştir. Böyle bir dönemde, "internette varolmayan bir hareketin gerçek yaşamda varolması olasılı̆̆ı bile artık olası gözükmemektedir”. Fakat unutulmamalıdır ki, eğer bir hareket reel hayatta kitleleri harekete geçirme potansiyeline sahip değilse, varlığının söylemsel düzeyde kalması kaçınılmazdır. Sanal ortamdaki etkin oluş kendisine toplumsal yaşamda bir 
karşılık bulamıyorsa, söz konusu hareket etkisiz ve toplumdan kopuk olarak tanımlanmaktadır (Çoban, 2011, s. 8).

2011 sonrası meydana gelen toplumsal hareketlerde internet kullanımının göz ardı edilemez bir etkisi olsa da, bu hareketlere gösterilen ilginin kaynağı ne Facebook, ne Twitter, ne de herhangi bir başka sosyal medya platformundaki paylaşımlardır. İlginin kaynağı, eylemcilerin hareketlerin ortaya çıktığı merkezlerdeki meydanları fiziksel olarak işgal etmiş olmalarıdır. "Söz konusu hareketlerin hepsi, sokaklarla meydanların kamusal kullanım ve siyasal örgütlenme doğrultusunda sahiplenilmesi talebinde bulunarak, 'kamusal mekânın ele geçirilmesi' [...] mücadelesine katılmışlardır" (Gerbaudo, 2014, s. 19). Bununla birlikte atlanmaması gereken asıl nokta, sosyal medyanın yalnızca soyut fikirlerin iletilmesini mümkün kılan bir araç değil, aynı zamanda insanları bir araya getiren ve onların birlikte hareket etmelerini sağlayan Gerbaudo'nun ifadesiyle kolektif eylemin koreografisini oluşturmada etkin olarak kullanılabilen - iki yönlü bir araç olduğu gerçeğidir. Bu doğrultuda sosyal medyanın günümüzdeki toplumsal hareketlerde gazete, afiş, broşür, vb. araçların işçi hareketi açısından oynadığı role karşılık gelen bir tarzda kullanıldığını söylemek mümkündür. Gerbaudo’nun (2014) ifadesiyle, "sosyal medya esas olarak, son derece dağınık ve bireysel davranan bir kitlenin fiziksel biçimde toplanmasını kolaylaştıran ve bunda kılavuz rolü oynayan, sembolik bir kamusal alan kurma süreci şeklindeki bir araya gelme koreografisinin kurulmasının sorumluluğunu üstlenmiş haldedir” (s. 6-9).

Öte yandan, kolektif hareket edebilir olmanın yanı sıra, muhalif bir hareketin siyasal ve toplumsal alanda etkin olabilmesi, toplumsal düşünüş biçimindeki iktidar etkisinin kırılmasıyla mümkündür. Bu bakımdan, muhalif ideolojinin kitlelere aktarımında, alternatif/muhalif medya kanallarının oluşturulması son derece önemlidir. Muhalif söylemler, bu kanallar vasıtasıyla toplumsallaştırılarak, toplumsal iletişimin etkin birer belirleyeni kılınmaya çalışılır. İktidarın iletişimsel alandaki hegemonyası ancak bu şekilde kırılabilecektir. Aslında toplumsal yaşayış içinde "muhalefet süreklidir, ama çoğu kez gizil bir haldedir" (Arrighi, Hopkins ve Wallerstein, 1995, s. 34). Muhalif medya kanallarıyla toplumsal yapıda içkin olan bu gizil muhalif eğilimlerin açığa çıkarılması gerekmektedir. Toplumsal hafızada ortaya çıarılacak olan muhalif kırılmalar, iktidarın toplumsal ve siyasal yaşamdaki etkisini giderek zayıflatacaktır. Çoban’ın (2011) da belirttiği gibi, "muhalif düşüncenin toplumsal bellekte yaşayan nüvelerinin alternatif medyalar tarafından güncel politik yaşama dair alternatif bakışları geliştirmeleri bu süreçte önemli olanakları sağlayabilir" (s. 5). Bu anlamda, "her toplumsal hareket tarihsel bağlamına uygun medyaları kullanarak kendi sesini duyurmuş ve tarihsel bir etki bırakmıştır” (Çoban, 2009, s. 4748).

Lenin (1990), kitleleri harekete geçirmek ve amaca uygun olarak yönlendirebilmek için döneme uygun medyaların olmazsa olmaz olduğunun altını çizer. Çünkü radikal bir toplumsal dönüşümün yaratılabilmesi, öncelikle toplumun düşünce dünyasının devrimcileştirilmesiyle mümkündür. Bu bağlamda Lenin’e göre, "güçlü siyasal örgütleri eğitebilmek için, bütün Rusyàyı kapsayan bir gazeteden başka araç" yoktur (s. 156). Marx da, Rheinische Zeitung'da yazı işleri müdürlüğü görevini yürütürken, gazetenin içeriği şu iki siyasal amaç üzerinde yoğunlaşmaktaydı: İlk olarak, "birleşmiş ve demokratik bir Almanya" ve ikinci olarak, "dışarıda devrimci insanları 
destekleme ve devrim düşmanı Rusyảya karşı savaş" (Erdoğan, 2007, s. 231). Gazete, sisteme muhalif devrimci ideolojinin üretildiği ve kitlelere sunulduğu bir merkez olmasının yanında, devrimci hareketin yönetim ve iletişim merkezi konumundaydı. Zira Marx, gazete yöneticiliği yaptığı dönemde, devrimci eylemin tutarlı bir şekilde sürdürülebilmesi adına propagandist ve etkili bir gazete yaratmak için çalışmıştır (Çoban, 2014, s. 156).

Özetlemek gerekirse, "yeni bir dünyanın mümkün olduğunun gösterilmesi ve bu dünyanın kurulabilmesi için kitlelerin harekete geçirilebilmesi öncelikle etkili bir sinıfsal hareketin ve buna bağlı radikal medyanın yaratılmasını gerektirmektedir" (Çoban, 2009, s. 61). Bu anlamda, günümüz koşullarına en uygun radikal medyanın, sosyal medya olduğunu söylemek yanlış olmayacaktır. Gerbaudo’nun (2014) aktardığı, Mısırlı bir eylemcinin dudaklarından dökülen şu cümle, sosyal medyanın bir araya gelme koreografisinde üstlendiği araçsal rolü net olarak ortaya koymaktadır: "Facebook tarih belirlemeye yararken, Twitter lojistik paylaşmakta, YouTube ise dünyayı göstermekte kullanılıyor ve hepsi birlikte insanları birbirlerine bağlıyorlar". Bu sözlerden de görülebileceği gibi, sosyal medya platformları bir taraftan harekete dahil olan eylemcilere nasıl davranmaları gerektiği konusunda reçeteler sunarken, diğer taraftan onları protesto eylemlerine katılma konusunda ikna eden araçlara dönüşmüş durumdadır (s. 5).

Toplumsal hareketler bağlamında yeni medya araçlarının kullanımı, diğer bir ifadeyle dijital aktivizm, hem sokaktaki faaliyetleri örgütlemek adına bir iletişim kanalı olarak hem de doğrudan ortamın kendisiyle sınırlı faaliyetler biçiminde karşımıza çımaktadır (Uçkan'dan aktaran Çayır, 2018, s. 56). Bir dijital aktivizm örneği olarak video aktivizmde de bir taraftan kamusal alanda meydana gelen olaylar kayıt altına alınırken diğer taraftan da bu kayıtlar, dijital ortamlar aracılığıyla hem sahadaki hem de bilgisayarı başındaki eylemcilere ulaştırılır. Böylece video, sokak ile sibermekan arasındaki bağlantıyı kurarken, çevrimiçi ve çevrimdışı direniş de birbirini tamamlar (Şener, 2018, s.94). Böylelikle bugün çevrimiçi dünyanın, Gerbaudo’nun (2014) ifadesiyle, "internetteki katılımcıların ortaklaşa paylaşılan semboller etrafında toplandıkları ve hayal kırıklığına uğrama, öfke ve daha iyi gelecek umuduyla karışan duygusal enerji biriktirdikleri bir yer" (s. xiv) durumuna gelmesiyle sosyal medya, çevrimdışı dünyadaki eylemciler için bir rehber olmanın yanı sıra bir motivasyon aracı haline gelmiştir.

Sosyal medya aracılığıyla kurulan bu duygudaşlık sayesinde, eski toplumsal hareketlerde sahada görmemizin pek mümkün olmadığı orta sınıftan birçok genç sokağa çıkmaya ikna olmuştur. Bugün kapitalizmin ulaştığı son noktada, yönetenler ve yönetilenler arasındaki sınır daha da netleşirken, kötü giden ekonomi, yozlaşmış siyasal sistem, artan polis şiddeti ve kamusal alanların yokluğu, vb. tüm yönetilenlerin ortak sorunları haline gelmiş görünmektedir. Toplumun her kesiminden insan, bu kötü gidişten farklı şekillerde etkilenmekteyse de, birleşilen ortak problemler karşısında kolektif bir aidiyet ve dayanışma duygusu geliştirilebilmektedir. Gerbaudo (2014), "bu bağlamda sosyal medya, birbirlerinden ayrı bireylerin ortak semboller ve yerler etrafında yakınlaşmalarını kolaylaştırarak ve onların çeşitliliğe rağmen, birlik sağladıklarına işaret ederek, kolektif toplanmanın aracı işlevini görmüştür" demektedir (s. 25). Diğer bir ifadeyle, sosyal medya aracığıyla çoğulcu iddialar ortak bir öznede bir araya getirilmektedir. Bu noktada, çalışmanın konusunu teşkil eden video aktivizmi var eden temel niteliklerin, toplumsal hareket 
ve eylem biçimlerinin değişen yapısı, dijital görüntü sistemlerinin ortaya çıması ile devamında görsel içerik üretiminin demokratikleşip ağ kültüründe sürekli bağlantıda olma hali olduğunu hatırlamak yerinde olacaktır (Şener, 2018, s.88).

\section{Aktivist Bir Eylem Olarak Video Aktivizm}

Video aktivizmin tarihini sinemadan bir örnekle 1920’li yıllara kadar götürmek mümkün. Sovyet sinemasında Ekim Devrimi’ni takip eden dönemde Dziga Vertov tarafından oluşturulan "herhangi bir işbölümü olmadan, denetlenmeyen bir akışın içindeki makinesel ve kolektif imaj üretimine dayanan muhabir ağıyla haberler, imajlar üretmiş Kinok adı verilen topluluklara" ilk video aktivistler gözüyle bakmamız yanlış olmayacaktır (Şener, 2018, s. 87; Berensel, 2017, s. 122). Bununla birlikte, $1920^{\prime} l i$ yılların işçi ve köylü kinokları ile bugününün video aktivistleri arasında ilişki kurmak da mümkündür; çünkü “Vertov’un medya profesyonelleri veya sanat elitleri yoktur, onun propaganda filmleri çekmek için yollara düşen kinokları, yani sine-gözlü devrimcileri; işçileri ve köylüleri vardır". Özetle her iki tarafın da öznesi bizzat yaşamın üreticisi amatörlerdir. Bunun yanında, kinok ${ }^{1}$ kavramının yaratıcısı Vertov’a göre kamera, gerçekliği olduğu gibi yakalayan pasif bir kayıt cihazı olmanın ötesinde, aktivist/eylemci bir araçtır da (Depeli, 2017, s. 111-114). Buna göre,

Vertov kamera teknolojisinin endüstriyel olan ile bağlantısını koparır, film kamerasını profesyoneller yerine kinoklara verir. Bu önemli bir müdahaledir: Üretilen gerçekliği güç ve endüstri bağlarından kurtarır, böylece nereden bakıldığına ve üretildiğine bağlı olarak gerçekliğin niteliği de değişir. Nitekim Vertov sinemasında gerçekliğin üreticileri işçilerdir. Bu Vertov’un medya araçlarının demokratikleşmesi adına en devrimci katkılarından biridir. [...] Günümüzde video aktivistlerin temel düsturlarından biri olan "değişim yaratma"yı Vertov 1930'larda, (propagandatif) filmleriyle, işte bu bakış ve gerçeği yaratma cesaretiyle yapar. (Depeli, 2018, s. 42-43)

Bugünlere gelirken video aktivizmin ilk örneği olarak nitelendirilebilecek olay, 5 Mart 1991 tarihinde Los Angeles'taki South Central'da yaşanmıştır. Afro-Amerikalı Rodney King, motoruyla aşırı hız yaptığı gerekçesiyle polisler tarafından durdurularak sokak ortasında öldüresiye dövülür. Bu esnada olan bitene kişisel video kamerasıyla evinin balkonundan tanıklık eden George Holliday'in çektiği görüntü, prime-time saatinde tekrar tekrar ekranlara gelir. Yalnızca 81 saniye süren bu görüntünün hızla dünyaya yayılmasıyla başlayan sokak gösterileri ve olayda sorumluluğu bulunan polislere açılan davalar, video kameraların toplumsal adalet mücadelesinde ne kadar önemli bir araç haline geleceğinin ilk sinyalini verir. Bu olay "kişisel video kameranın bir nostalji aksesuarından öte toplumsal adaleti iyileştirme ve insan hakları savunuculuğu için etkili ve yaygın bir araca dönüşmesine yardım” eder (Widgington, 2015, s. 113).

"Kinok, Dziga Vertov’un icat ettiği bir kavram. Kinok Rusçadaki sinema anlamına gelen kino sözcüğüyle, Rus dilinin eski edebi bir sözcüğü olan göz anlamına gelen oko sözcüklerinden türetilmiş ve kamerayla dolaşıp kenti görüntüleyen toplumsal bir tipi de işaret ediyordu" (Berensel, 2017, s. 122). 
Video kameraların günlük hayattaki hak ihlallerini belgelemedeki rolü açısından bir milat sayılabilecek Rodney King olayının ardından, Amerika'da Witness video kolektifi kurulur. Özellikle bu kolektifin kurulmasının ardından, daha önceleri profesyonel fotoğrafçılar tarafından belgelenen savaş, protesto ve insan hakları ihlalleri gibi olaylar, kamera sahibi amatör yurttaşlar tarafından belgelenerek dolaşıma sokulur hale gelir (Şener, 2018, s. 100). Ege Berensel'in (2017) de belirttiği gibi,

90’ların başından itibaren video kameraların küçülmesi, ucuzlaması ve artık cep telefonlarına bile entegre ediliyor olması, kurgu programlarının artık ev bilgisayarında kullanılıyor olması, sivil toplumun aynı yıllarda güçlenmesi sosyal adalet için video aktivizmi ortaya çıkardı ve insan hakları mağdurlarının, sesleri işitilemez olanların sesi biraz olsun video sayesinde işitilir oldu. (s. 121)

İlk kez bu yıllarda internet kullanımının hızla yaygınlaşmaya başlayıp video paylaşım ve veri iletim hızlarının giderek artması, ana akım medya tarafından görmezden gelinmiş olay ya da eylemlerin görüntülerini kayıt altına alarak dijital platformlar üzerinden yayan, toplumsal sorunlar ve hak ihlalleri karşısında mücadele veren medya aktivistlerini ortaya çıkarmıştır (Berensel, 2017, s. 122). Berensel'in de ifade ettiği gibi, özellikle 1990'lı yılların başlarında, sıradan insanın hayatına girmeye başlayan dijital teknolojiler sayesinde, görüntü kaydetmenin ve kaydedilen görüntünün insanlara ulaştırılmasının giderek daha ekonomik bir hale gelmesi, video aktivizmin önünü açmıştır. Bugün, bir araya gelmenin koreografisini oluşturmada internet görsellerinin belki de en etkilisi olan videonun yaratıcısı video aktivisti, reel dünyadaki değişimlere etkin olarak destek sağlayabilmektedir. Bununla birlikte, video sanatı ile video aktivizm arasındaki ilişkiyi 1960’lı yılların ortalarına kadar götürmek mümkündür. İlk kez bu dönemde ortaya çıkan taşınabilir video cihazı Sony Portapak’la birlikte analog görüntü kaydetme ve kimyasal film işleme süreci yerini dijital veri işlemeye bırakmıştır. Böylelikle sıradan bireyin enformasyon üretim sürecine katılımının ve kendi görüşlerini dile getirebilmesinin de önü açılmıştır (Taylan, 2018, s. 30).

Cris Michael'in (2011) video aktivistlerin eylem sürecini görüntülerken dikkat etmeleri gereken noktaları on maddede bir araya getirdiği yazısından hareketle, video aktivizmin iki önemli aşaması bulunduğunu söyleyebiliriz. İlk aşamada bir video aktivisti, olay esnasında kameraya aldığı görüntüleri online platformlarda ya da veri depolama aygıtlarında saklayarak koruma altına alır. Bununla birlikte, elindeki görüntülerin geniş kitlelerce izlenebilmesi için gerekli adımları atar. Bunlara ek olarak, aktivistin eylem anı olay yerinden canlı olarak yapacağı görüntü ve ses aktarımı (stream yayın) da video aktivist bir eylem olarak kabul edilebilir. İkinci olarak, video aktivist bir eylemde bulunmak isteyen kişi, hazırladığı görüntülerin doğrudan üreticisi olmak zorunda değildir. Başkalarınca kaydedilen görüntülerin montajlanarak bir araya getirilmesiyle ortaya çıkarılan kurgulanmış yeni bir görüntü de video aktivist bir eylem içinde kullanılabilmektedir.

Kısaca video aktivizm, protesto anı kaydedilen görüntülerin, olayın üzerinden çok zaman geçmeden montajlı ya da ham bir şekilde insanlara ulaştırılması durumunu da, bu görüntülerin 
başka aktivistlerce kurgulanarak yaratılan yeni bir video içinde sunulması durumunu da kapsamaktadır. Özellikle ikinci durumda, kişilerce - aktivist olsun ya da olmasın - kaydedilen görüntülerin dijital platformlarda herkesin kullanımına açık bir şekilde sunuluyor olması önemlidir. Böylece bir video aktivisti, çekimin gerçekleştirildiği anda olay yerinde bulunamasa dahi, paylaşıma açık olarak sunulan bu görüntülerden bir kolaj yaratarak video aktivist bir eylemde bulunabilmektedir. Böylelikle video aktivizm, anlık bir eylem olmanın ötesine geçerek aktivizmde kolektif katkıyı besleyen bir sürece dönüşmektedir.

\section{Bir Araya Gelmenin Koreografları: Video Aktivistler}

Dijital aktivist, siber ortamlar dışında da aktivist eylemlerde bulunan, bununla birlikte, hiçbir siyasal kurum tarafından temsil edilmediğini düşünen sıradan insana sosyal medya platformları aracılığıyla ulaşarak onu da inandığı değerler doğrultusunda harekete geçirmeye çalışan kişidir. Bu doğrultuda bir dijital aktivist, kamusal bir alanda düzenlenecek olan fiziksel toplanmayı ya da ortadan kaldırılması düşünülen probleme karşı yürütülen bir kampanyayı, sosyal medya üzerinden örgütler. Bu bağlamda Gerbaudo (2014), dijital aktivistleri toplumsal eylem hareketlerinin koreografları olarak tanımlamaktadır. Ona göre, "etkili Facebook sayfa yöneticileri (admins) ve eylemci twit yoldaşları, zeminin belirlenmesinde ve içinde kolektif eylemin serpilebileceği bir duygusal alanın kurulmasında söz sahibi, 'yumuşak liderler' (soft leaders), yani koreograflar durumuna gelmişlerdir" (s. 9). Bu bağlamda bir video aktivisti, yeni toplumsal hareketlerin koreograflarından biri olarak tanımlamak yanlıs olmayacaktır. Çünkü bugün, dünyanın her yerinde video aktivistler "yaratıcı ve stratejik yollarla video çekiyor, sesi çıkmayanları işitilir kılmak için elde ettikleri görüntü ve sesleri kullanmaya devam ediyorlar ve önemli reformların hayata geçirilmesini” sağllyorlardır (Gregory, 2007, s. 5). Bir video aktivist her zaman, konu ne olursa olsun olan biteni eylemcilerin olduğu konumdan görmeye, o noktadan video çekmeye çabalamaktadır. Böylelikle eylemde aktif olan kişilerle, videoyu izleyenler arasında bir duygudaşlık kurulabilmesi amaçlanmaktadır (Metin, 2017, s. 154).

İnsanlar tarafından sosyal medyanın derin bir duygusallıkla, arkadaşlık ve mahremiyet alanları içinde her gün yoğun olarak kullanılması, onu yeni toplumsal hareket "liderleri", diğer bir ifadeyle koreografları için cazip bir araç haline getirmiştir. Çünkü sosyal medya paylaşımları sadece bilgilendirme amacıyla kullanılmazlar; aynı zamanda, insanlardaki bireysel öfke, nefret, gurur ve ortak mağduriyet duygularının toplumsallaşmasını sağlayarak, ortak bir amaç doğrultusunda onları harekete geçirmek için de kullanılmaktadırlar. Bugünkü toplumsal hareketlerde bir nevi duyguları iletme kanalı olarak da işlev gören sosyal medya platformları, dağınık yerlerdeki eylemciler ve toplumsal olarak farklı kesimlerden insanları harekete geçirmede kullanılmaktadır (Gerbaudo, 2014, s. xiv-xvii).

Tipkı dijital aktivist gibi, video aktivisti de toplumsal adaleti mümkün kılmak için çabalamaktadır, fakat genel aktivist tanımından farklı olarak video aktivisti amacına ulaşmak için kamerayı bir araç olarak kullanan ve görsel imgelerin gücünün farkında olan kişidir. Onun için "kamera; toplumsal değişim için tıpkı bir megafon, bir dava, bir kutu sprey boya, bir internet sitesi 
ve/veya bir şiir gibi diğer seçenekler arasında yer alabilecek bir seçeneğe dönüşür" (Widgington, 2015, s. 108-109). Toplumsal değişim yaratma gayesiyle kamerayı eline alan video aktivisti, elde ettiği görüntüleri insanlara ulaştırarak, onları değişim yönünde harekete geçirmeyi amaçlar. Thomas Harding (2001), bir kameranın video aktivistinin ellerinde polis şiddetini caydırıcı güçlü bir siyasi araca, bir kurgu setinin politik gündem belirleme aracına, bir projeksiyon cihazının ise kitlesel farkındalık oluşturan bir mekanizmaya dönüşebileceğini belirtmektedir (s. 1-2). Şurası açıktır ki, bugün insan hakları hususunda yetkisini kötüye kullanan devlet görevlilerinin, video kanıtının var olduğu durumlarda bu suçlardan paçayı kurtarması çok daha zordur, çünkü video, "bir durumun görsel bir 'kanıtı' olduğu kadar; doğrudan doğruya insan hakları konusunda karar alan organlar, bir hükümetin politika yapıcıları, bir topluluk ya da küresel kamuoyu” önünde son derece etkili olabilmektedir (Gregory, 2007, s. 1-8).

Bir video aktivistini önemli kılan şey, olayları hem polis barikatının içinden hem de dışından görüntülüyor olmasıdır. $\mathrm{O}$, ana akım medyanın dışarıdan bir bakışla kameraya aldığı olayları, doğrudan olayın kalbinin attığı noktadan görüntülemektedir (Widgington, 2015, s. 111). Gülsüm Depeli'nin (2018) sözleriyle, "o orada toplumsal vicdan adına tanıklık eden olarak bulunur; müsebbipler değil mücadele edenler, şiddete meşruluk kıllfi türetenler değil, ifş̧a belgesi türetenler tarafında konumlanır" (s. 45). Böylece gerçeklik "en saf haliyle" ortaya konabilmektedir. Zaten sistem içinde varlı̆̆ını sürdüren bir medyanın, sisteme karşı gelişen bir hareketi doğru bir şekilde yansıtması beklenmemelidir. Sokağa çıkan eylemcilerin çektiği görüntüler, ana akım televizyon kanallarının suskunluğa gömüldüğü dönemlerde önemli birer bilgi ve delil kaynağı olabilmektedir. Aktivist bir video, halka ana akım tarafından gösterilmeyerek yok sayılan gerçekleri gösterirken, onları egemen medya tarafından üretilen yalanlardan koruyarak harekete geçmeye teşvik eder (Metin, 2017, s.152).

Video aktivisti, olay anı olan biteni tüm gerçekliğiyle kameraya almaktaysa da, aktivist bir video, "gerçekliğin bir parçasını yakalamaya çalışan belgesel" türüyle kesinlikle karıştıılmamalıdır. Aktivist video örnekleri birçok farklı tarz ve türde karşımıza çıkabilmektedir. Toplumsal bir mesele hakkında insanları harekete geçirmek için kurmacadan animasyona, parodi haberlerden müzik kliplerine kadar pek çok farklı türde aktivist video üretilebilmektedir. $\mathrm{Bu}$ nedenle, bir video aktivistinin yaptığı işi, toplumsal hareketlerde eylemcileri takip etmek ve tutuklama anlarını kameraya almakla sınırlı görmek yanlış olacaktır (Widgington, 2015, s. 118). Bununla birlikte, kişisel ya da toplumsal herhangi bir mesele video aktivizmin konusu olabilir, "çünkü kitlesel olaylar, kurulu düzene yönelik örgütlü suçlamaları tekeli altına almaz. Yüksek oranda öznel referanslar ve derin kişisel deneyimler de statükocu politikalara ve bakış açılarına meydan okuyabilir" (Widgington, 2015, s. 110). Buna paralel olarak bir video aktivist, kendisini asla tarafsız olmak zorunda hissetmez. Onun tarafı bellidir: toplumsal adalet. Lakin tarafsız olmamakla birlikte, "kamusal tartışmalara ilham verecek ve değişimi sağlayacak eylemi teşvik edecek marjinal ya da başka türlü fikirleri” sunmak için yoğun çaba sarf eder (Widgington, 2015, s. 110). Depeli’nin (2018) de ifade ettiği gibi,

Video aktivistin herhangi bir medya endüstrisi ve/ya sermaye ile bağı yoktur. Egemen olanın dili, medyası ve kurumları ile aynı safta durmaz, aksine, onların karşısındadır. 
O daha ziyade egemenin hedef alanındakilerin, toplumun, mücadelenin tarafındadır.

Klasik bir haberciden farklı olarak kaydettiği olayın dışında değil, içindedir. Dolayısıyla tarafsızlık ve nesnellik gibi nosyonlara zaruri olarak mesafelidir. (s. 36)

Video aktivist tarafından kaydedilen görüntüler daha sonradan ham ya da kurgulanmış bir şekilde sosyal medya platformları üzerinden insanlara ulaştırılmaktadır. Böylece görüntüleri izleyen insanlarda oluşturulan "bir arada hareket etme" ve "ben de bir şey yapmalıyım" duygusu, onları sokağa çıkmaya ya da farklı bir alanda harekete geçmeye ikna edebilmektedir. Video aktivizmi, yurttaş gazeteciliğinden ayıran en temel nokta tam da burasıdır: video aktivizmde, daha adil bir toplum için direnmeye davet vardır. Özetle video aktivizm, "toplumsal aktörlerin katılımını ve bilincini harekete geçirmeye, diyalog ve düşünümsellik için ve egemen toplumsal düzenden kopuş için kolektif alanları artırmaya; müşterek bilginin ve öz deneyimlerin değerli kılınmasına ve kolektif eylem süreçlerinin birbirine eklemlenmesine hizmet eder" (Cabellero'dan aktaran Şener, 2018, s. 96).

\section{Gezi Parkı Eylemleri ve Video Aktivizm}

Video aktivizmin Türkiye'deki serüvenine odaklandığımızda, 1970'lerde toplumsal olay ve eylemlerin görüntülerini kayıt altına alan Genç Sinema Hareketi’ni bir mihenk taşı olarak kabul edebiliriz (Berensel, 2017, s. 123). Türkiye’de bugünkü anlamılla video aktivizm ise, öncesinde toplumsal hareketleri fotoğraf makineleriyle görüntülüme çabasındaki aktivistlerin yavaş yavaş ellerine kameralarını aldıkları 2008 yılıyla birlikte ortaya çıkmışır. Bu tarihten itibaren, gelişen teknolojiyle birlikte videonun dijital platformlar üzerinden daha kolay yayınlanabilir olmasıyla pek çok farklı kolektif, kendi web sayfaları üzerinden videolarını paylaşmaya başlamıştır (Erensoy, 2018, s. 184). Video aktivist oluşumlar başlığı altında ülkemizden Videa, Karahaber, Seyr-i Sokak, Bak.ma, Vidyoccupy, İnadınaHaber, Kamera Sokak gibi kolektifler örnek verilebilir.

Mayıs 2013'ün son günlerinde Taksim Gezi Parkı’ndan başlayarak ülkenin birçok kentine yayılan eylemler, Türkiye'de video aktivizm konusunda dönüm noktalarından biri olarak kabul edilmektedir. Gezi Parkı eylemlerine katılmış pek çok genç, yalnızca cep telefonlarının yardımıyla olan biteni kayıt altına alırken, elde ettiği görüntüleri başka insanlarla paylaşmıştır. Böylelikle ifade özgürlüğüne ve bilgiye dolaysız ulaşım hakkına önem veren gençler, bu beklentilerini karşılayamayan ana akım medya karşısında alternatif iletişim kanallarını üretmiş oldular (Metin, 2018, s. 219). Öte yandan, video aktivistler de eylemler boyunca sokaktaki yerlerinden ayrılmamışlardır. Sokakta olma amaçları, ana akım medya tarafından gösterilmeyeni göstermektir. Bununla birlikte, bir taraftan yayınladıkları video içeriklerle eylemin örgütlenmesine rehberlik ederken, bir taraftan da sokakta olmayanların sokağa inmelerini sağlayarak eylemin devamlılığına katkıda bulunmaya çalışıyorlardı (Ocak, 2017, s. 157-158). Sonuç olarak, benzer amaçlarla üretilmiş çok sayıda video içerik neticesinde Gezi Parkı eylemleri bugün, "Türkiyedde en fazla kayıt altına alınmış toplumsal hareketlilik olarak şimdiden tarihe" geçmiş durumdadır (Aytaç, 2013, s. 68). 
Gezi Parkı eylemlerinde, bir araya gelmenin koreografisi bağlamında video aktivizmin gücünü en net ortaya koyan gerçek, 27 Mayıs gecesi Taksim Gezi Parkı’nda yaklaşı 50 kişilik bir aktivist grupla başlayan sürecin, 79 ilde 2,5 milyon insanın katılımıyla ${ }^{2 *}$ gerçekleşen geniş çaplı bir eyleme dönüşmüş olmasıdır. Bu bağlamda, Gezi Parkı eylemlerini analiz edebilmek adına, eyleme katılım gösteren kişiler hakkında bir takım bilgilere ihtiyaç duyulmaktadır. İhtiyaç duyulan bilgiler, KONDA Araştırma ve Danışmanlık Şirketi tarafından hazırlanan Gezi Raporu'nun (2014) verilerinden elde edilmiştir. Rapordan kullanılan veriler, 2013 yılının 6-8 Haziran tarihleri arasında Taksim Gezi Parkı içerisinde ve 6-7 Temmuz tarihleri arasında Türkiye genelinde gerçekleştirilen araştırmalardan elde edilmiştir. ${ }^{3 * *}$

İlk olarak, Gezi Parkı'nda bulunan eylemcilerin yaş dağılımlarına baktığımızda \%5,5'inin 18 yaşın altında, \%16,5'inin 18-20 yaş aralığında, \%30,8'inin 21-25 yaş aralığında, \%20,3'ünün 26-30 yaş aralığında, \%10,8'inin 31-35 yaş aralığında ve \%16,1'inin ise 35 yaşın üstünde olduğu görülmektedir (KONDA, 2014, s. 6). Eylemcilerin eğitim seviyeleri incelendiğinde \%0,3’ünün okuryazar olmadığı, \%1,1'inin diplomasız okuryazar olduğu, \%2,7'sinin ilkokul mezunu, \%5,7'sinin ortaokul mezunu, \%34,5'inin lise mezunu, \%42,8'inin üniversite mezunu ve \%12,9'nun da yüksek lisans/doktora mezunu oldukları anlaşılmaktadır (KONDA, 2014, s. 9). Meslek alanlarına göre bir gruplamaya gidildiğinde ise \%4'ünün devlet memuru, \%15'inin özel sektör çalışanı beyaz yakalı, \%6'sının işçi, \%2'sinin küçük esnaf, \%5'inin serbest meslek sahibi, \%3’ünün emekli, \%2'sinin ev hanımı, \%37'sinin öğrenci, \%17'sinin diğer işlerde çalışan ve \%5'inin de işsiz oldukları belirtilmiştir (KONDA, 2014, s. 11).

Eylemcilere, İstanbul'un neresinden geldikleri sorusu yönelttiğinde Kadıköy \%13,4, Şişli \%11,4, Beşiktaş \%7,3, Üsküdar \%5,8 ve Fatih \%5,4'le başı çekse de toplamda 40'ya yakın ilçeden Gezi Parkı’na katılımın olduğu görülmektedir (KONDA, 2014, s. 12). Gezi Parkı’ndaki eylemcilere herhangi bir siyasi partiye, oluşuma veya dernek, vakıf, platform gibi bir oluşuma üye olup olmadıkları sorulduğunda \%21,1’i üye olduklarını söylerken, \%78,9’u üye olmadıklarını belirtmişlerdir. Bununla birlikte, "Gezi Parkı’nda sade vatandaş olarak mı, yoksa herhangi bir grubu, oluşumu vs. temsilen mi bulunuyorsunuz?” şeklindeki soruya ise \%93,6 gibi yüksek bir oranda "sade vatandaş olarak" yanıtının verildiği görülmektedir (KONDA, 2014, s. 14).

Gezi Parkı eylemcilerinin taleplerine dair yöneltilen soruya verilen yanıtlar ise \%34,1 oranda "Özgürlükler için", \%18,4 oranda "Hak ihlallerine karşı, hak talebi için", \%9,7 oranda "Diktatörlüğe, baskıya karşı", \%9,5 oranda "Yönetim istifa", \%8 oranda "Demokrasi ve barış için", \%6,2 oranda "Polis şiddetine karş", \%6,1 oranda "Destek vermek, dayanışma için", \%4,6 oranda "Ağaç kesilmesin, kışla yapılmasın diye", \%3,2 oranda "Devrim" ve \%2,5 oranda "Sesimizin duyulması için" şseklinde sıralanmaktadır. Verilen yanıtlarda, eylemcilerin neredeyse onda

2 http://www.milliyet.com.tr/2-5-milyon-insan-79-ilde-sokaga/gundem/detay/1726600/default.htm

3 "Raporda kullanılan veriler 6-8 Haziran 2013 tarihlerinde Gezi Parkı̉nda 4411 kişi ile gerçekleștirilen Gezi Parkı araştırmamıza ve Temmuz ayı KONDA Barometresi1 için 6-7 Temmuz 2013 tarihlerinde 2629 kişi ile 28 ilde Türkiye’nin 18 yaş üstü yetişkin nüfusunu temsil edecek şekilde yapılan araştırmaya dayanmaktadır”" ("Gezi Raporu", 2014, s. 3). 
dokuzunu parka getiren nedenin doğrudan devlet politikalarının işleyişi ile alakalı olduğu görülmektedir (KONDA, 2014, s. 19).

Yukarıdaki veriler incelendiğinde Gezi Parkı eylemcilerinin toplumun farklı kesimlerinden gelen, çeşitli meslek gruplarına mensup, çoğunluğu öğrenci gençlerden ve yükseköğretim mezunlarından oluşmakla birlikte farklı yaş gruplarından ve çeşitli eğitim seviyelerinden kişiler oldukları görülmektedir. Bu doğrultuda, Gezi Parkı’ndaki kalabalığı, bir araya gelmiş çokluklar şeklinde tanımlamak yanlıs olmayacaktır. Bununla birlikte, parktakilerin herhangi bir siyasi parti ya da ideolojinin doğrudan etkisi altında bulunmadan, devlet politikalarından memnuniyetsiz olma ortak paydasında birleşerek hareket etmeleri, günümüzün yeni toplumsal hareketlerinin karakteristiğiyle de uygunluk göstermektedir. Aynı zamanda toplumda "orta sınıf" olarak tanımlanabilecek kesimlerin Gezi Parkı eylemlerinde çoğunluğu oluşturmaları, yeni toplumsal hareketlere karşılık gelen bir başka özellik olarak önümüzde durmaktadır. Son olarak, Park’ta bulunan eylemcilerin çoğunluğunun, toplumda "okumuş" kesimler olarak nitelenen üniversite öğrencisi ve yükseköğretim mezunu gençlerden oluştuğu görülmektedir. Tüm bu veriler bir araya getirildiğinde, Gezi Parkı eylemlerinin günümüz yeni toplumsal hareketlerine tam karşılık gelen yapısı görünürlük kazanmaktadır.

Daha önce herhangi bir protesto, yürüyüş ya da oturma eylemine katılıp katılmadıkları yönündeki bir soruya, eylemciler tarafından \%55,6 gibi bir oranda olumsuz yanıt verilmiştir. $\mathrm{Bu}$ doğrultuda, Gezi Parkı’ndaki eylemcilerin \%44,4’ünün, gerçekleşmesi muhtemel herhangi bir toplumsal harekete aktif olarak katılım gösterebileceğini söyleyebiliriz (KONDA, 2014, s. 15). Eylemcilere hangi noktada parka gelmeye karar verdikleri sorusu yöneltildiğinde, \%10,2'sinin “Taksim projesinin duyduğunda", \%19'unun "Ağaçları sökmeye giriştiklerinde", \%49,1'inin "Polis şiddetini görünce", \%14,2'sinin "Başbakan Tayyip Erdoğan’n açıklamalarını duyunca", \%4,3'ünün "Taksim’deki ortamı görünce" şeklinde yanıtlar verdikleri görülmüştür. Bu oranlara bakarak eylemcilerden yüzde 49,1'inin, yani hemen hemen her iki eylemciden birinin polis şiddetine karşı tepki olarak parka geldiğini kabul edebiliriz. Bu noktada, polis şiddetinin pek çok eylemci için önemli bir dönüm noktası olduğunu söylemek yanlış olmayacaktır (KONDA, 2014, s. 18).

Eylemcilerin Gezi Parkı’ndaki gelişmelerle ilgili ilk haberi aldıkları kaynağın ne olduğu, çalışma açısından önem arz etmektedir. Zira Haziran'13 araştırmasından elde edilen verilere göre Gezi Parkındaki eylemcilerin \%15,1'i ilk haberi bir arkadaşından ya da tanıdığı birinden; \%69'u sosyal medya üzerinden; \%8,6'si internet haber sitelerinden; \%7'si ise televizyondan aldığını belirtmiştir. Öte yandan, Türkiye genelinde gerçekleştirilmiş olan Temmuz'13 Barometre araştırmasının verilerini incelediğimizde ise oranlarda önemli farklar dikkat çekmektedir. Buna göre, Türkiye genelinde insanların \%5,3’ünün Gezi Parki’yla ilk haberi bir arkadaşından ya da tanıdığı birinden; \%15,9'unun sosyal medya üzerinden; \%6,4’ünün internet haber sitelerinden; \%71,3’ünün televizyondan aldığı; \%1,2'sinin ise olaylardan hiç haberinin olmadığı görülmektedir (KONDA, 2014, s. 22-23).

Yukarıda eylemciler tarafından verilen yanıtlarda şu iki veri dikkat çekmektedir: Birincisi eylemcilerin büyük bir çoğunluğunun "Polis şiddetini görünce" parka gelmeye karar vermiş 
olması, ikincisi ise ilk haberin $\% 77,6$ oranda (\%69'u sosyal medya üzerinden, \%8,6'sı internet haber sitelerinden olmak üzere) dijital medya platformlarından edinilmiş olması. Bu noktada, Gezi Parkı eylemlerinin ilk günlerinde polis şiddetini ifşa eden videoları hatırlamak yerinde olacaktır. Eylemcilerin verdiği yanıtlardan toplanan veriler analiz edildiğinde, 28 Mayıs'ta iş makinalarının Gezi Parkı’na girmesi sonucu 50 kişilik eylemci bir grupla başlayan Gezi Parkı eylemlerinin (“Yıkım Nöbeti”, 2013), 31 Mayıs'ta ülkenin farklı bölgelerine yayılan geniş çaplı bir toplumsal harekete dönüştüğü süreçte internet üzerinden sunulan videoların son derece etkili olduğu söylenebilir. 28 Mayıs’ta gaz maskeli bir polis tarafından, daha sonraları "Kırmızlı Kadın" olarak anılacak olan bir eylemcinin yüzüne çok yakın mesafeden biber gazı sıkıldığı görüntülerin yer aldığı video (“Ağaçlar Böyle Söküldü”, 2013) ile parktaki eylemci çadırlarının ateşe verildiği, yoğun biber gazlı sert polis müdahalesinin görüntüleri (“Kim Bunlar!", 2013) eyleme katılımı biraz daha arttırmışsa da özellikle 31 Mayıs'ta polisin eylemcilerden birine TOMA'yla yakın mesafeden tazyikli suyla müdahalede bulunduğu anın video görüntüsü (“Toma’ya Yumruk Atan”, 2013) ile başına gaz kapsülü isabet eden Filistin asıllı Türkiye vatandaşı bir eylemcinin ("Taksim'de Titreyerek", 2013) video görüntülerinin internette dolaşıma girmesi, eyleme katılımın artmasında ve olayların ülke çapına yayılmasında ön ayak olmuştur. Bu doğrultuda, Gezi Parkı'ndaki eylemcilerin \%55,6’sının daha önce herhangi bir eyleme katılmamış olmaları da göz önüne alındığında video aktivizmin, Gezi Parkı eylemlerinin henüz tüm ülkeye yayılmadığı ilk üç günde son derece etkili olduğu sonucu ortaya çıkmaktadır. Kısaca söylemek gerekirse video aktivistler, Gezi Parkı eylemlerinde bir araya gelmenin koreografisini oluşturmada etkin rol oynamışlardır.

\section{SONUÇ}

Toplumda yabancılaşmanın, tarihte daha önce hiç görülmemiş boyutlara ulaştığı bir dönemde fikirlerini ortaya atan Marx, toplumsal hareketlerin öznesi olma umudunu proletaryaya bağlamaktaydı. Çünkü ona göre toplumların tarihi, sınıf savaşımlarının tarihiydi ve proletarya, kapitalizmin içinde barındırdığı çelişkilerden de faydalanarak beklenen devrimi gerçekleştirecekti. Ancak, Marx’nn bu düşüncesinin temelinde yer alan eksiklik; proletaryanın da, onun karşısına konumlandırılan burjuvazinin de evrensel, değişmez ve yekpare örgütlenmeler şeklinde ele alınmasıdır. Oysa durum, günümüzde bir miktar değişmiş görünmektedir.

Tarihin yazılmaya başlandığı günden bugüne kadar ortaya çıkan her türlü bilimsel ve teknolojik gelişme, egemen sınıfın baskı ve denetim metotlarını daha gelişkin bir seviyeye ulaştırmasının aracı olmuştur. Özellikle Sanayi Devrimi’ni takip eden süreçte meydana gelen gelişmelerle, toplumun denetim mekanizmaları giderek daha rafine bir hal alırken; iktidar, kamusal alandan mahrem alana kadar heryerdeliğini artan bir biçimde hissettirmektedir. Lakin tarihin bu ilerleyişi, bir taraftan bireyin yaşam alanının tümünde iktidarı gizil ama etkin kılarken, diğer taraftan da bireye merkezsiz ve parçalanmış bir iktidar yapısı karşısında yeni direniş kanalları açmaktadır. Yani, günümüzde iktidarın çatlaklarından kendi yolunu bulması gereken bu yeni direniş biçimi de karşıtı gibi merkezsiz ve çoğulcudur. 
Peki, çok parçalı ve gelecekten farklı beklentilere sahip olan birbirine benzemez bu kalabalıklar nasıl bir araya gelmektedirler? Nasıl olup da tek bir amaç için sokaklara dökülebilmektedirler? Bu soruların yanıtını yeni medya teknolojilerinde bulmak mümkündür. Özellikle son yirmi yılda yeni iletişim teknolojilerinde yaşanan gelişmeler, sıradan insanın çalışma alanını fabrikadan plazaya taşırken, pek çok güncel problemi de insanlığın ortak sorunu haline getirmiştir. Bugün bu teknolojiler sayesinde zaman ve mekanın sınırlılıklarından kurtulan birey, ulusal ya da yerel çapta kendisiyle benzer kaygılar taşıyan insanlarla iletişime geçebilmekte ve ortak bir zeminde hareket edebilmektedir. İnsanları, ortak sorunlar karşısında birlikte hareket etmeye motive eden duygudaşlı̆̆ın kurulması da yine bu teknolojilerin imkân verdiği sosyal ağlar üzerinden sağlanmaktadır. Söz gelimi, Taksim Gezi Parkı eylemleri öncesinde sosyal medya, hareketin örgütlenmesinde aktif olarak kullanılmamışsa da, sonraki süreçte hareketin tüm ülkeye yayılmasında ve toplumsal bir harekete dönüşmesinde genelde sosyal medyanın, özelde ise video aktivizmin rolünün ön plana çıktığını söyleyebiliriz. Atılan twitler ve paylaşılan görseller bir taraftan olan biten hakkında bilgi sahibi olunmasını sağlarken diğer taraftan farklı toplumsal yapılara mensup bireylerin ortak bir kimlikte bir araya gelmelerini mümkün kılmıştır. Bu noktada özellikle video, hem sesi hem de görüntüyü bir arada sunmasıla insan duygularına en fazla hitap edebilen teknoloji olarak, toplumsal hareketlerin örgütlenme sürecinde, diğer bir ifadeyle bir araya gelmenin koreografisini oluşturmada etkili bir motivasyon aracı olarak öne çıkmaktadır. Bu teknoloji, bir video aktivistinin ellerinde, daha güzel bir dünyaya dair etkin bir araca dönüşebilir ve insanın özgürleşme sorunu karşısında yeni bir umut kapısını aralayabilir. 


\section{Kaynakça}

Ağaçlar böyle söküldü [Video dosyası]. (2013, 28 Mayıs). Hürriyet.com.tr. http://www.hurriyet.com.tr/ video/taksim-gezi-parki-nda-agaclar-boyle-sokuldu-77993 adresinden erişilmiştir.

Arrighi, G., T.K. Hopkins ve I. Wallerstein. (1995). Sistem karşıtı hareketler. C. Kanat, B. Somay ve S. Sökmen (Çev.). İstanbul: Metis Yayınları.

Aytaç, S. (2013). Gezi Parkı kayıtları. Olgu, Güliz (Videooccupy), Zeynep Dadak, Elif Ergezen ve Necati Sönmez ile söyleşi. Altyazı, 130, 68-76.

Bayhan, V. (2014). Yeni toplumsal hareketler ve Gezi Parkı direnişi. Birey ve Toplum, 4(7), 23-57.

Berensel, E. (2017). Gerilla televizyonundan video-aktivizme, şahit-videosundan medya-aktivizme: Video ile nasıl direnilir? E. Berensel (Der.). Videonun Eylemi içinde (s. 121-126). İstanbul: Alef Yayınevi.

Castells, M. (2008). Ağ toplumunun yükselişi / Enformasyon çağı: Ekonomi toplum ve kültür (Birinci Cilt). E. Kılıç (Çev.). İstanbul: Bilgi Üniversitesi Yayınları.

Castells, M. (2013). İsyan ve umut ağları / İnternet çağında toplumsal hareketler. E. Kılıç (Çev.). İstanbul: Bilgi Üniversitesi Yayınları.

Coşkun, M. K. (2006). Süreklilik ve kopuş teorileri bağlamında Türkiye'de eski ve yeni toplumsal hareketler. Ankara Üniversitesi SBF Dergisi, 61(1), 67-102.

Çayır, F. (2018). Dijital bir hak mücadelesi olarak video aktivizm ve video aktivistlerin yaşadığı hukuki sorunlar. G. Şener ve N. Gider Işıkman (Der.). Video aktivizmde kavramlar, sorunlar, uygulamalar içinde (s. 55-86). Ankara: um:ag Vakfı Yayınları.

Çayır, K. (1999). Toplumsal sahnenin yeni aktörleri: Yeni sosyal hareketler. K. Çayır (Ed.). Yeni sosyal hareketler / Teorik açılımlar içinde (s. 13-34). İstanbul: Kaknüs Yayınları.

Çoban, B. (2009). Toplumsal hareketler ve radikal medya. B. Çoban (Haz.). Yeni toplumsal hareketler: Küreselleşme, direniş, ütopya içinde (s. 43-62). İstanbul: Kalkedon Yayınları.

Çoban, B. (2011). Toplumsal hareketler ve yeni alternatif - radikal medyalar. Yeditepe Üniversitesi İletişim Çalışmaları Dergisi. 14, 1-14.

Çoban, B. (2014). Radikal medya ile “ne yapmalı?”: Lenin’in geri dönüşü. B. Yanıkkaya ve B. Çoban (Der.). Kendi medyanı yarat: Alternatif medya / Kavramlar, tartışmalar, örnekler - Cilt 2 içinde (s. 131-176). İstanbul: Kalkedon Yayınları.

Depeli, G. (2017). Temsilin ötesine geçmek. E. Berensel (Der.). Videonun eylemi içinde (s. 95-119). İstanbul: Alef Yayınevi.

Depeli, G. (2018). Video aktivizm ve etik: Gerçeklik, tanıklık, bakış. G. Şener ve N. Gider Işıkman (Der.). Video aktivizmde kavramlar, sorunlar, uygulamalar içinde (s. 36-54). Ankara: um:ag Vakfı Yayınları.

Erdoğan, İ. (2007). Karl Marx: Basın özgürlüğü ve sansür. İletişim Kuram ve Araştırma Dergisi, 25, 229-256.

Erensoy, Ş. F. (2018). Röportaj: Tanıklıktan öz-kayıta video eylemcinin konumu: Karahaber ve Seyr-i Sokak örnekleri. G. Şener ve N. Gider Işıkman (Der.). Video aktivizmde kavramlar, sorunlar, uygulamalar içinde (s. 172-206). Ankara: um:ag Vakfı Yayınları.

Gabriel, P. (2007). Önsöz. S. Gregory, G. Caldwell, R. Avni ve T. Harding (Ed.). Değiştirmek için video: Gör, filme çek, değisştir içinde (s. 1-3), (Çev. D. Dölek). İstanbul: Versus Yayınları.

Gerbaudo, P. (2014). Twitler ve sokaklar. O. Akınhay (Çev.). İstanbul: Agora Kitaplığı.

Gregory, S. (2007). Giriş. S. Gregory, G. Caldwell, R. Avni ve T. Harding (Ed.). Değiştirmek için video: Gör, filme çek, değiştir içinde (s. 5-11), (Çev. D. Dölek). İstanbul: Versus Yayınları.

Hank, J., E. Larana ve J. R. Gusfrield. (1999). Kimlikler, şikayetler ve yeni sosyal hareketler. K. Çayır (Ed.). Yeni sosyal hareketler / Teorik açılımlar içinde (s. 131-159). İstanbul: Kaknüs Yayınları. 
Harding, T. (2001). The video activist handbook. London: Pluto Press.

Hardt, M. ve A. Negri. (2004). Çokluk: İmparatorluk çağında savaşve demokrasi. B. Yıldırım (Çev.). İstanbul: Ayrıntı Yayınları.

Kim bunlar! Taksim'deki o olayın görüntüleri ortaya çıktı [Video dosyası]. (2013, 30 Mayıs). Hürriyet. com.tr. http://www.hurriyet.com.tr/video/kim-bunlar-taksim-deki-o-olayin-goruntuleri-ortayacikti-78085 adresinden erişilmiştir.

KONDA. (2014). Gezi raporu/Toplumun 'Gezi Parkı Olayları’ algısı/Gezi Parkındakiler kimlerdi? 07.04.2018 tarihinde http://konda.com.tr/wp-ontent/uploads/2017/02/KONDA_GeziRaporu2014.pdf adresinden edinilmiştir.

Laclau, E. ve C. Mouffe (1992). Hegemonya ve sosyalist strateji. A. Kardam ve D. Şahiner (Çev.). İstanbul: Birikim Yayınları.

Lenin, V. İ. (1990). Ne yapmalı?. M. Erdost (Çev.). Ankara: Sol Yayınları.

Marx, K. ve F. Engels (2015). Komünist manifesto. C. Üster ve N. Erdiş (Çev.). İstanbul: Can Sanat Yayınları.

Metin, O. (2017). Kameraları evden sokağa, eyleme çıkarmanın vaktidir. E. Berensel (Der.). Videonun eylemi içinde (s. 151-158). İstanbul: Alef Yayınevi.

Metin, O. (2018). Video aktivizmin Türkiye serüveni / BalıkBilir - İnadına haber. G. Şener ve N. Gider Işıkman (Der.). Video aktivizmde kavramlar, sorunlar, uygulamalar içinde (s. 215-229). Ankara: um:ag Vakfı Yayınları.

Michael, C. (2011). Top 10 tips for filming \#occupy protests, arrests \& police conduct. 17.11.2017 tarihinde https://blog.witness.org/2011/11/top-10-tips-for-filming-occupy-protests-arrests-police-conduct/ adresinden erişilmiştir.

Morozov, E. (2017). Facebook ve Twitter sadece devrimcilerin gittiği yerlerdir. F. Aydoğan (Der.). Yeni medya kuramcılarından yeni medya kuramları içinde (s. 23-27), (Çev. Y. Göksun) İstanbul: Der Yayınları.

Ocak, E. (2017). Gezi Direnişi’nin belgeselleri nasıl yapılacak? Kavramsal bir çerçeve denemesi. Toplum ve Bilim Dergisi, 140, 155-180.

Offe, C. (1999). Yeni sosyal hareketler: Kurumsal politikanın sınırlarının zorlanması. K. Çayır (Ed.). Yeni sosyal hareketler / Teorik açılımlar içinde (s. 53-80). İstanbul: Kaknüs Yayınları.

Önder, T. (2003). Ekoloji, toplum ve siyaset. Ankara: Odak Yayınevi.

Sabanc1, A. A. (2017, 8 Haziran). Online’ım, öyleyse varım! Hürriyet. http://www.hurriyet.com.tr/kitapsanat/onlineim-oyleyse-varim-40483921 adresinden erişilmiştir.

Şener, G. (2018). Sosyal ağlarda video aktivizm. G. Şener ve N. Gider Işıkman (Der.). Video aktivizmde kavramlar, sorunlar, uygulamalar içinde (s. 87-105). Ankara: um:ag Vakfı Yayınları.

Şentürk, Ü. (2006). Küresel yeni sosyal hareketler ve savaş karşıtlığı. Cumhuriyet Üniversitesi Sosyal Bilimler Dergisi, 30(1), 31-46.

Taksim'de titreyerek kurtarılmayı bekledi! [Video dosyas1]. (2013, 31 Mayı). Hürriyet.com.tr. http:// www.hurriyet.com.tr/video/taksim-de-titreyerek-kurtarilmayi-bekledi-gezi-parki-olaylari-78133 adresinden erişilmiştir.

Taylan, A. (2018). Alternatif medya ve video aktivizm. G. Şener ve N. Gider Işıkman (Der.). Video aktivizmde kavramlar, sorunlar, uygulamalar içinde (s. 14-35). Ankara: um:ag Vakfı Yayınları.

Tomàya yumruk atan eylemcinin sonu [Video dosyas1]. (2013, 31 Mayı). Hürriyet.com.tr. http://www. hurriyet.com.tr/video/toma-ya-yumruk-atan-eylemcinin-sonu-78118 adresinden erişilmiştir.

Touraine, A. (1995). Modernliğin eleştirisi. H. Tufan (Çev.). İstanbul: YKY. 
Widgington, D. (2015). Devrimi izlettirmek: Video aktivizmiyle ilgili sıkça sorulan sorular. A. Langlois ve F. Dubois (Der.). Otonom medya: Direnişi ve muhalefeti canlandırmak içinde (s. 108-128), (Çev. G. Şener). İstanbul: Epsilon Yayıncilık.

Yıkım nöbeti [Video dosyası]. (2013, 28 Mayıs). Hürriyet.com.tr. http://www.hurriyet.com.tr/video/taksimgezi-parki-nda-yikim-nobeti-77983 adresinden erişilmiştir. 